Verhaegen, H., De Crée, J. \& Brugmans, J. (1973a) Treatment of aphthous stomatitis. Lancet, ii, 842.

Verhaegen, H., De Crée, J., De Cock, W. \& Verbruggen, F. (1973b) Levamisole and the immune response. New England Journal of Medicine, 289, 1148.

Verhaegen, H., De Crée, J., Verbruggen, F., Hoebeke, J.,
De Brabander, M. \& Brugmans, J. (1973c) Immune responses in elderly cuti-negative subjects and the effect of levamisole. Verhandlungen der deutschen Gesellschaft für innere Medizin, 79, 623.

VidebacK, A. (1962) Cyclic neutropenia. Report on three cases. Acta medica scandinavica, 172, 715.

Postgraduate Medical Journal (August 1976) 52, 514-517.

\title{
Carcinoid tumour of the ampulla of Vater associated with cutaneous neurofibromatosis
}

\author{
P. V. BARBER \\ M.B., M.R.C.P. \\ North Manchester General Hospital
}

\begin{abstract}
Summary
A case of carcinoid tumour of Vater's ampulla is described from a patient with widespread cutaneous neurofibromatosis. The literature concerning the few known cases of carcinoids occurring at this site is briefly reviewed and the presentation, prognosis and treatment discussed, together with the possible significance of such a clinical association.

\section{Introduction}

Carcinoid tumours arising in the ampulla of Vater are extremely rare, comprising about $0.3 \%$ of gastrointestinal carcinoids. The following case is believed to be the thirteenth in the literature and is of especial interest, since the patient also suffers from Von Recklinghausen's disease, a condition known to be associated with a variety of tumours of neural origin. The present case presented with obstructive jaundice and was successfully treated by local excision.
\end{abstract}

\section{Case report}

A 30-year-old male was admitted for investigation. Ten months previously he had noticed that his stools had become pale and offensive and his urine dark. Shortly afterwards he developed generalized pruritus and became deeply jaundiced. He had also lost some weight, and complained of upper abdominal discomfort. The jaundice regressed several weeks later but subsequently increased progressively.

At the age of 17 years, he had begun to develop multiple skin tumours of the trunk and limbs. There was no family history of this condition and no significant previous medical history.
On examination, he was deeply jaundiced. There were multiple sessile and pedunculated tumours involving the skin of almost the whole body, and several large café-au-lait patches on the back. Th8 liver was greatly enlarged, firm and non-tende? There was no clinical evidence of hepatic failure of portal hypertension. Rectal examination revealea pale faeces. There were no other abnormal findings.

Significant laboratory findings included a serum bilirubin of $7.8 \mathrm{mg} / 100 \mathrm{ml}$, an alkaline phosphatase of $95 \mathrm{KA}$ units $/ 100 \mathrm{ml}$ and an elevated serum globulin at $4 \mathrm{~g} / 100 \mathrm{ml}$. Haemoglobin and blood count were within normal limits apart from a slight lymphopenia; the ESR was elevated to $63 \mathrm{~mm} / \mathrm{hr}$. The urine was strongly positive for bilirubin and contained no urobilinogen.

Plain radiology of the abdomen showed only an enlarged liver, and a barium series showed no displacement or filling defect of the duodenum.

A diagnosis of post-hepatic obstructive jaundice was made and laparotomy was performed shortly after admission. The liver was enlarged and smooth, and the gall-bladder distended. The spleen was also slightly enlarged. The stomach, duodenum and pancreas were normal but there was a mobile nodule o involving the ampulla of Vater. The nodule was $N$ excised completely and the common bile duct anastomosed to the duodenum. The pancreatic duct was found to exit below the common bile duct. The duodenum was closed and a liver biopsy taken. A skin tumour was removed, and was subsequently shown to be a neuro-fibroma.

Post-operative recovery was uneventful, and the serum bilirubin fell rapidly to normal levels. Urinary 


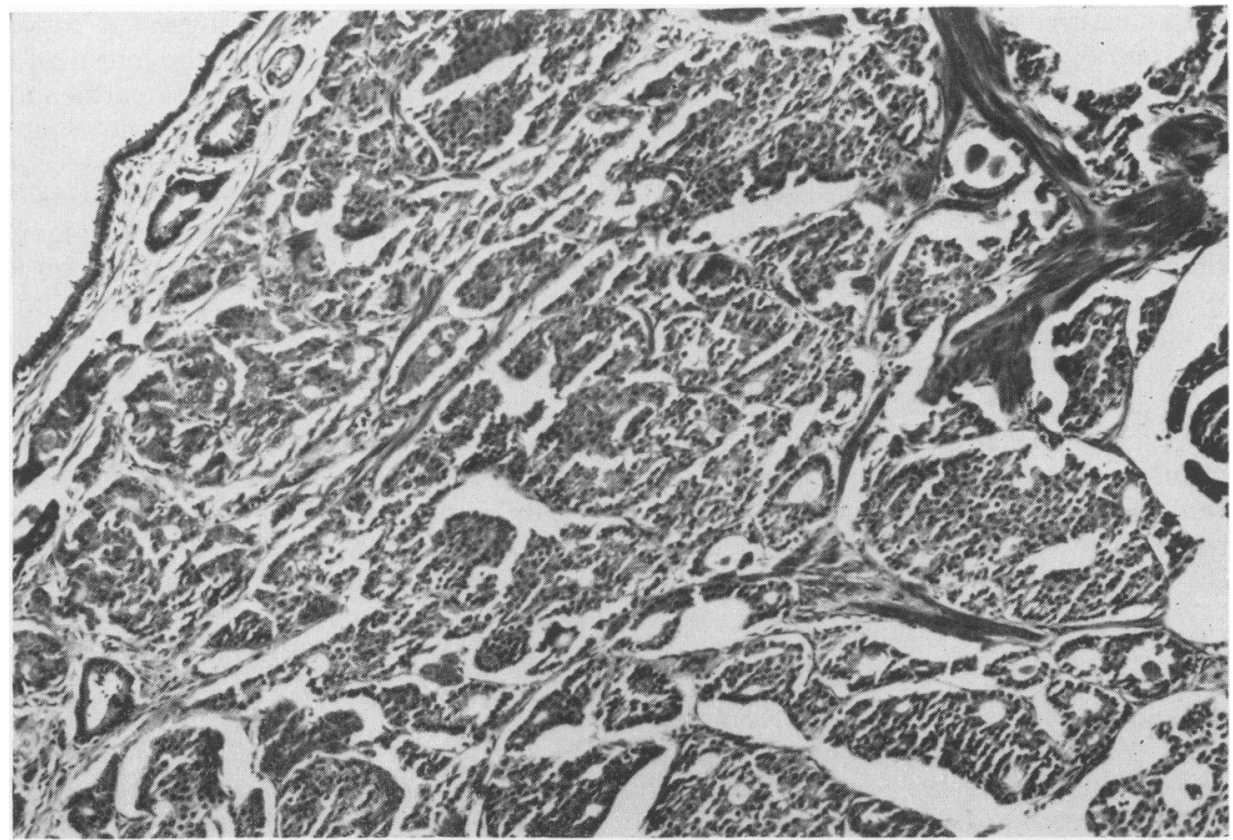

FIG. 1. Carcinoid tumour of ampulla of Vater showing typical alveolar arrangement of epithelial cells. Common bile duct epithelium can be seen at the margin of the tumour. $\times 100$.

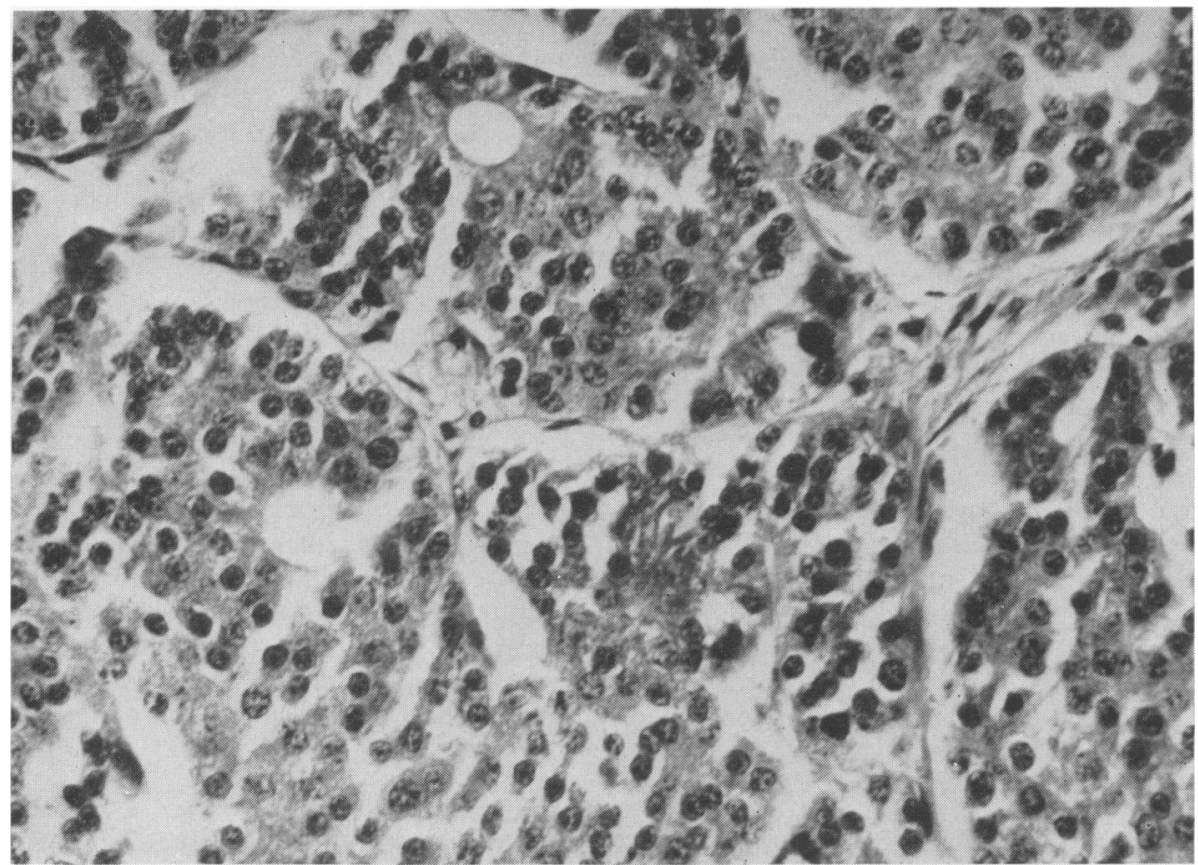

FIG. 2. High power view of tumour showing fairly uniform polygonal cells with granular cytoplasm. Poorly formed acini are seen. $\times 320$. 
5-HIAA levels measured post-operatively were found to be normal, and the liver biopsy showed only the features of extra-hepatic obstruction. The patient was discharged after a few days and has remained well up to the present time.

Macroscopically, the specimen consisted of ampulla of Vater with overlying duodenal mucosa and part of bile duct. On section the ampulla was largely replaced by a well defined greyish yellow tumour $1.3 \mathrm{~cm}$ in diameter.

Histologically, the lesion showed the typical appearance of a carcinoid, with groups of small, pale staining, closely-packed polyhedral cells showing some acinar formation (Fig. 1). Cytologically, the lesion was benign but showed some evidence of local infiltration (Fig. 2). The argentaffin reaction was negative (see Discussion).

\section{Discussion}

Carcinoid tumours of the duodenum comprise approximately $2 \%$ of gastro-intestinal carcinoids. Ampullary carcinoids are even less common. Sanders' collected series of 2,502 cases (Sanders and Axtell, 1964) included only eight involving the ampulla. In all, the author has been able to locate twelve examples excluding the present case (Sanders and Axtell, 1964; Moreaux, Martin and Bloch, 1971; Stefanini, Urbas and Crockett, 1970; Torres, 1953; Macrae and Conn, 1959; Brunschwig and Childs, 1939).

Von Recklinghausen's disease is known to be associated with a large number of tumours of neural origin, including meningioma (Penfield and Young, 1930), phaeochromocytoma (Davis, Hull and Vardell, 1950), acoustic nerve tumours and gliomas (Roberts, 1967; Barnard and Lang, 1964), spongioblastoma of the cerebellum and optic chiasma (Fulton and Bailey, 1930; Barnard and Lang, 1964) and malignant schwannoma (Dehner and Smith, 1970). An association with carcinoids is not generally recognized, although a patient has been reported with generalized cutaneous and visceral neurofibromatosis and a phaeochromocytoma of one adrenal in whom a duodenal carcinoid was an incidental finding at post-mortem (Lee and Garber, 1970).

It is also known that patients with carcinoids have a high incidence of other neoplasia, Kuiper's series (Kuiper, Gracie and Pollard, 1970) giving a figure of $31 \%$. However, these were mainly visceral carcinomas, although two patients in the same series had meningiomas. Other than these, there is no reported association with neurofibromas or other neural tumours.

The origins of the cells from which carcinoid tumours arise is not fully established. Ectodermal origins have been proposed (Raiford, 1932; Boyd,
1960) while others have suggested endodermal or mesenchymal sources from the intestinal crypt cells (Foley and Davis, 1965; Azzopardi and Pollock, 1963; Gibbs, 1962; Williams and Sandler, 1963; Popoff, 1939; Masson, 1928). More recently, Pearse has characterized carcinoids as arising from cells belonging to the APUD (amine precursor uptake and decarboxylating) cell system, and considers that, while there is some degree of overlap with the endodermal 'parakrine' system described by Feyrter (1954), APUD cells must be regarded as derivative of the neural crest (Pearse and Welbourn, 1973). A neuro-ectodermal origin, if proved, would help to explain the association reported here.

An argentaffin reaction was not demonstrated in the present case. Duodenal carcinoids frequently show no granular staining with either diazo or argentaffin techniques and do not fluoresce after conventional aldehyde fixation (Morson and Dawson, 1972).

\section{Course and management of ampullary carcinoids}

Ampullary carcinoids present early, owing to their situation. All save two have presented with jaundice. No patient had obvious symptoms of pancreatic obstruction, although Brunschwig's case ha $\$$ steatorrhoea (Brunschwig and Childs, 1939) and mann volunteered non-specific dyspeptic symptoms. Probo ably the accessory pancreatic duct, opening distally to the ampulla remains patent when the duodenal end of the main duct is obstructed. No case was diagnosed pre-operatively and no case was associated with the carcinoid syndrome or with elevated hydroxy-indole excretion.

These tumours run a fairly benign course. One of the documented cases died 1 year after local resection. Two patients died from metastases 15 months and 4 years respectively after treatment. The remainder have remained well for periods varying from 1 to 7 years. Of these, seven were treated by local excision only. If the pancreatic duct is not involved, this form of treatment can be expected to yield good results with respect to operative complications. If the duct is involved, the operative morbidity is higher and some advantages of local excision are lost. In these instances, particularly with more extensive local involvement, a more radical pancreatic-duodenectomy has been used. In the present case, excision presented no great problems, and was thought surgically and histologically to be complete.

\section{Acknowledgments}

I am grateful to Dr Philip Markman and Mr Richard Hartley for permission to publish this case, and to $\mathrm{Dr} D$. de Kretzer, who reported the histology and provided the photomicrographs. 


\section{References}

Azzopardi, J.G. \& Pollock, D.J. (1963) Argentaffin and argyrophil cells in gastric carcinoma. Journal of Pathology and Bacteriology, 86, 443.

BARNARD, R.O. \& LANG, E.R. (1964) Cerebral and cerebellar gliomas in a case of Von Recklinghausen's disease with adrenal phaeochromocytomas. Journal of Neurosurgery, 21, 506.

BOYD, J.D. (1960) Origin, development and distribution of chromaffin cells. Ciba Foundation Symposium on Adrenergic Mechanisms, p. 63. Churchill, London.

BRUNSCHWIG, A. \& CHILDS, A. (1939) Resection of carcinoma (carcinoid?) of the intrapapillary portion of the duodenum invading the ampulla of Vater. American Journal of Surgery, 45, 320.

Davis, F.W., Hull, J.G. \& Vardell, J.C. (1950) Phaeochromocytoma with neurofibromatosis. American Journal of Medicine, 8, 131

DehNer, L.P. \& SMith, B.H. (1970) Soft tissue tumours of the penis. A clinico-pathologic study of 46 cases. Cancer, New York, Philadelphia, etc., 25, 6, 1431.

Feyrter, F. (1954) Für Pathologie des argyrophilen HelleFellen-Organes im Bronchialbaum des Menschen. Virchows Archiv für pathologische Anatomie und Physiologie und für klinische Medizin, 325, 723.

Foley, J.F. \& DAvis, R.B. (1965) Growth of carcinoid tumours in tissue culture. Nature, London, 205, 785.

Fulton, J.F. \& Bailey, P. (1930). Nueva contribucion sobre los tumores del tercer ventriculo. Sa associacion con el sindrome de Recklinghausen y con el edema de Quincke.

GibBs, N. M. (1962) The histogenesis of carcinoid tumours of the rectum. Journal of Clinical Pathology, 16, 205.

Kuiper, D.H., Gracie, W.A. \& Pollard, H.M. (1970) Twenty years of gastro-intestinal carcinoids. Cancer, New York, Philadelphia, etc., 25, 6, 1424.
LEe, H.Y. \& GARBER, P.E. (1970) Von Recklinghausen's disease associated with phaeochromocytoma and carcinoid tumour. Ohio Medical Journal, 66, 6, 583.

MACRAE, J.M. \& CoNN, J.H. (1959) Carcinoid of the ampulla of Vater. Surgery, 46, 902.

Masson, P. (1928) Carcinoids (argentaffin cell tumours) and nerve hyperplasia of the appendicular mucosa. American Journal of Pathology, 4, 181.

Moreaux, J., Martin, E. \& Bloch, P. (1971) Les tumeurs carcinoïdes de l'ampoule de Vater. Chirurgie, 97, 473.

MoRson, B.C. \& DAwson, I.M.P. (1972) Gastro-Intestinal Pathology, p. 358.

Pearse, A.G.E. \& Welbourn, R.B. (1973) The apudomas. British Journal of Hospital Medicine, 10, 5, 617.

Penfield, W. \& Young, A.W. (1930) The nature of Von Recklinghausen's disease and the tumours associated with it. Archives of Neurology and Psychiatry. Chicago, 23, 320.

Popoff, N.W. (1939) Epithelial functional rejuvenation observed in the mucous cells of the gastro-intestinal tract and the parietal cells of the stomach. Archives of Pathology, 27, 841 .

RAIFORD, T.S. (1932) Tumors of the small intestine. Archives of Surgery, 25, 122.

ROBERTS, A.H. (1967) Association of a phaeochromocytoma and cerebral gliosarcoma with neurofibromatosis. British Journal of Surgery, 54, 78.

Sanders, R.J. \& Axtell, H.K. (1964) Carcinoids of the gastrointestinal tract. Surgery, Gynecology and Obstetrics, 119, 369.

Stefanini, M., Urbas, J.E. \& Crockett, F.L. (1970) Argentaffin carcinoma (carcinoid tumor) involving the ampulla of Vater. Illinois Medical Journal, 138, 2, 130.

Torres, A.L. (1953) Carcinoide de ampola de Vater. Arg. Inst. Biol. Excercito, 10-13, 53.

Williams, E.D. \& SANDler, M. (1963) The classification of carcinoid tumours. Lancet, i, 283. 